\title{
Comparative Study of the Perceptions of Mexican and Colombian Employees about Managerial and Leadership Behavioural Effectiveness
}

\begin{abstract}
Purpose

The purpose of this qualitative study was to compare the perceptions of employed people in Mexico and Colombia about managerial and leadership behavioural effectiveness.

\section{Research Design}

A qualitative multiple cross-case and cross-nation comparative analysis of findings obtained from the two past emic replication (Mexico and Colombia) studies was conducted.

\section{Findings}

Our study suggests that people within Mexican and Colombian organizations perceive 'managerial and leadership behavioural effectiveness' in very similar ways. Our findings support those researchers whose studies indicate that culture may not, as previously thought, play a significant role in the way managers should manage and lead their subordinates.

\section{Originality}

Our comparative study attempts to generate new insights and better understanding within the context of 'managerial and leadership behavioural effectiveness' research, which we hope will make a useful contribution to the existing small body of knowledge regarding similarities and differences in managerial practices across culturally diverse Latin American countries.

\section{Practical implications}

The findings of our comparative study are relevant to those HRD professionals in international companies with operations in Mexico and/or Colombia when preparing their executives for international assignments in these Latin American countries. 
Keywords: Managerial Effectiveness, Mexico, Colombia.

\section{Introduction}

Mexico and Colombia have always been close. They were once neighbours after their independence from Spain back when the Mexican Empire and the Gran Colombia were in place. Besides sharing colonial ties, they are both business allies. Mexico is the second largest LatinAmerican country in terms of investments in Colombia (Procolombia, 2018). Colombian FDI in Mexico is half as much but it is growing. In 2016, Mexico invested USD\$620 million in Colombia, and Colombia invested USD\$488 million in Mexico (Iglesias, 2017). Regional agreements such as the Pacific Alliance, which aims for deeper regional integration between Colombia, Chile, Mexico, and Peru through free movement of goods, services, resources, and people, helps keep the two countries working together (The Pacific Alliance, 2018). Early in 2014 , the alliance agreed to eliminate tariffs on $92 \%$ of trade among the countries currently participating. At the bilateral level, trade between Mexico and Colombia reached a peak of $\$ 6.4$ billion USD in 2012. Even though the current number has decreased to a little over $\$ 4$ billion in 2018 (Secretaria de Economia, 2018), as companies internationalize their operations in both countries, Mexican team leaders are assigned to Colombian employees and vice versa. This calls for high levels of cross-cultural competence in managing and leading employees who are not compatriots of the manager. Thus, the purpose of our study is to increase understanding of the similarities and differences between managerial and leadership practices of Mexican managers compared to those of Colombian managers.

Although much managerial (manager/leader) behaviour research has been conducted in Western countries on the specific issue of 'managerial and leadership behavioural effectiveness' (see for example Borman and Brush, 1993; Hamlin, 2009; Yukl et al., 2002; Yukl, 2012), little 
equivalent research has been carried out in Latin American countries despite the call of scholars for the need for management studies in this region of the world (e.g. Nicholls-Nixon et al. 2011; Elvira and Davila, 2005). Of the few studies that have been conducted, the most notable are those that we have carried out with various indigenous co-researchers in Argentina, Colombia, and Mexico. These qualitative managerial behaviour studies explored the specific issue of 'what behaviourally distinguishes effective managers from ineffective managers' within public and/or private sector organizations (Anon 1 et al. 2013; Anon 1 et al., 2016; Anon 3 et al., 2015). Furthermore, to our knowledge, the only contemporary researchers who have explored the similarities and differences in managerial behaviour across national boundaries within the Latin American region, other than those cited above, are two of us who have conducted a crosscase/cross-nation (Mexico-Argentina) comparative study (Anon 1 et al., 2018). Our current inquiry builds upon this latter study by similarly conducting a comparative analysis of findings obtained from the same Mexican qualitative managerial behaviour study (Anon 1 et al., 2013) and our more recent Colombian study (Anon 3 et al, 2015). The central question addressed was as follows: To what extent are the behavioural determinants of perceived managerial and leadership effectiveness within Colombia and Mexico similar or different?

Following the example of Anon 1 et al, (2018), our use of the term 'managerial and leadership effectiveness' refers to "the behavioural effectiveness of managers in performing their everyday tasks of managing and leading people" (Anon 1 et al., 2013, p. 131). Furthermore, it should also be noted that our use of the word 'leadership' relates to the 'supervisury leadership' (House and Aditya, 1997) performed by managers at all levels, and not to the 'strategic leadership' (House et al., 2004) additionally performed by organizational leaders and other top managers. 


\section{Literature Review}

In this section we focus first on providing a literature review of past research on 'management and '¿adership behavioural effectiveness' conducted in Mexico and Colombia, respectively. We then outline the two theories that guided our study and conclude with a statement of its purpose and the specific research questions that we addressed.

\section{Managerial and leadership behavioural effectiveness research in Mexico \\ The GLOBE (Global Leadership Organizational Behaviour Effectiveness) study (House} et al., 2004) suggests that certain leadership behaviours may be more effective than others within the context of the Mexican culture. The findings of House et al., (2004) suggest that high level executives in Mexico should be inspiring, competent, decisive, team players, and achievement oriented as these are behaviours that are valued by the Mexican workforce. Moreover, managers in Mexico should stay away from being autocratic, non- participative, malevolent, face-saver, and self-centred as these behaviours are perceived as ineffective.

Hofstede's (1980) cross-cultural study suggests that based on the Mexican culture, some managerial practices may be more effective than others. Hofstede's research found that Mexico is a collectivist society, meaning that Mexicans have a propensity to be part of a group where individuals take care of each other and where loyalty is highly valued and rewarded (Luthans and Doh, 2012). Yet, other studies such as the one conducted by Trompennars and Hampden-Turner (1998), indicate that Mexicans are less collectivist and more individualistic, suggesting that they may prefer individual work rather than group work. With regards to the dimension of 'uncertainty avoidance', the findings of Hofstede' study indicate that Mexicans are high on this dimension which suggests that employees in Mexico have a desire for job security, and that ${ }^{\text {they }}$ are averse to risk. Clear rules over ambiguity seem to be the preference of Mexican employees. 
Hofstede's study also found Mexicans scoring high on the cultural dimension of 'power distance.' This finding suggests they are comfortable with managers who exhibit an authoritarian leadership style. It also suggests that effective managers need to be very directive and that employees do not expect to be involved in decision making. Indeed, as various researchers argue, the Mexican management style can be categorized as authoritarian (Dorfman and Howell, 1997; Stephens and Greer, 1995).

The findings of Hofstede's (1980) cross-cultural study indicate that Mexicans scored high on 'masculinity' which, according to Luthans and Doh (2012), suggests that advancement, earnings, and recognition are important. Davis and Nayepour (2004) indicate that Mexican employees give preference to work, education, and training over leisure activities. Therefore, in order to motivate employees in Mexico, managers should address these preferences. Najera (2008) found that to be respected as a manager in Mexico, the following managerial attributes are required: showing flexibility, creating a congenial working environment, and providing appreciation and recognition. They suggested these attributes are important to Mexican employees.

Even though the research cited above suggests that there may be behavioural factors associated with effective management and leadership in Mexico, no ucip, were found that directly explore the specific managerial behaviours that differentiate effective managers from ineffective managers. The only studies we know of that directly address the topic of 'managerial and leadership behavioural effectiveness' are those that we have conducted in Mexico, as cited earlier. 


\section{Managerial and leadership behavioural effectiveness research in Colombia}

As in the case of Mexico, research that addresses the topic of managerial and leadership effer ${ }^{\prime}: v_{t}$ ness is very limited. Nevertheless, cross-cultural studies suggest that, given the culture of the cour.ry, some managerial practices may be more effective than others. For example, Hofstede's $(1,78 n)$, study indicates that Colombians are high on 'power distance', suggesting that employees are willing to receive orders from their supervisors without questioning them.

Moreover, this finding suggests that Colombians are comfortable with authoritarian managers who make decisions without necessarily consulting employees (Luthans and Doh, 2012).

Hofstede's study found Colombians being high on the cultural dimension of 'collectivism' (Luthans and Doh, 2012). A score high on collectivism indicates that relationship building and connections are relevant in Colombia. In terms of management, a high score on 'collectivism' suggests that Colombian managers may favour relationships over performance. Hence, they may prefer to hire employees based on relationships rather than qualifications, and to promote employees based on relationships rather than accomplishments.

Hofstede's cross-cultural study found Colombians scoring high on the dimension of 'uncertainty avoidance' which suggests that people in Colombia may not welcome ambiguous situations. From the managerial perspective, a high score on this dim ns - suggests that Colombians favour rules and regulations, and that they have a need for ser arity This implies that: i) to be effective, managers in Colombia should strive to provide a sense $\_$$\_$ecurity as employees tend to be risk averse; and ii) employees prefer those managers who provide clear directions and instructions over those managers who rely on a management style that is unclear. In terms of 'masculinity/femininity', Hofstede's study found Colombians scoring moderate to high on this cultural dimension which suggests they perceive as effective those managers who 
provide reward and recognition, and who care about the professional development and advancement of the workforce.

As is in the case of Mexico, the GLOBE study conducted by House et al. (2004) provides insight about leadership effectiveness in Colombia. Although the subject focus of the GLOBE research was on top managers, the findings could still have some relevance for managers at different levels in organizations. This cross-cultural study focused on identifying behaviours that enhance or inhibit effective leadership. The findings suggest that to be an effective leader in Colombia the following behaviours should be exhibited: team oriented, participative, charismatic, and human oriented. According to the GLOBE study, effective leaders should: i) be able to inspire their subordinates; ii) develop a sense of passion among subordinates (charismatic); iii) involve subordinates in decision making (participative); iv) promote team work and look for collaboration among the members of the team (team oriented); and v) care about the well-being of the workforce. Furthermore, the study suggests that in Colombia, being autonomous and self-centered as well as being self-protective (face saver) should be avoided because these attributes constrain leadership effectiveness.

Although the afore-mentioned studies suggests that certain managerial practices in Colombia may be related to effective management, none explicitly e $\operatorname{plc} r$ the issue of 'managerial and leadership behavioural effectiveness'. Like in the case of 'rlex co, the only research we have found in the literature that directly addresses this issue is a $r$ d that we have conducted in Colombia (Anon 3 et al, 2015).

\section{Theoretical context}

Our comparative study is framed on two theoretical concepts: the multiple constituency model of organizational effectiveness and reputational effectiveness respectively. According to the 
multiple constituency model, managers in organizations interact with multiple stakeholders such as peers, subordinates, and superiors. These stakeholders have their expectations about the behavioural performance of managers based on their implicit personal beliefs regarding what is a good (effective) and/or a bad (ineffective) manager (Tsui, 1990). The reputational effectiveness of a manager is then determined by how well he or she meets the expectations of the different stakeholders (Tsui, 1984, 1994). Stakeholder perceptions about the behavioural input performance of managers can have a positive or negative effect on their actual output performance (Tsui and Ashford, 1994). For instance, when colleague managers and subordinates perceive a manager as ineffective, this may result in an unwillingness to collaborate or to follow their leadership. Conversely, if they perceive a manager as effective, this may result in better collaboration and followership from colleague managers and subordinates, respectively, thus leading to better individual, team, and depar $\mathrm{m}$, ntai performance.

\section{Purpose of the study and research questions}

Our comparative study attempts to generate new insights and better understanding within the context of 'managerial and leadership behavioural effectiveness' research, which we hope will make a useful contribution to the existing small body of knowledge regarding similarities and differences in managerial practices across culturally diverse Latin American countries. As previously mentioned, it replicates Anon 1 et al.'s (2018) cross-case/cross-nation comparative analysis of findings from two qualitative managerial behaviour studies conducted in Argentina and Mexico, respectively.

The research questions we addressed were the following: 
RQ 1. What are the similarities and differences between the perceptions of Mexican and Colombian managerial and non-managerial employees about effective managerial behaviour?

RQ 2. What are the similarities and differences between the perceptions of Mexican and Colombian managerial and non-managerial employees about ineffective managerial behaviour?

RQ 3. Can the findings from RQ 1 and RQ 2 be integrated inductively and expressed in the form of generic behavioural indicators of perceived managerial ad leadership effectiveness?

\section{Methods}

This section describes our philosophical stance, the nature of our empirical source data and the methodology used for the source studies from $\mathrm{w}$ hich it was obtained, the research methods we

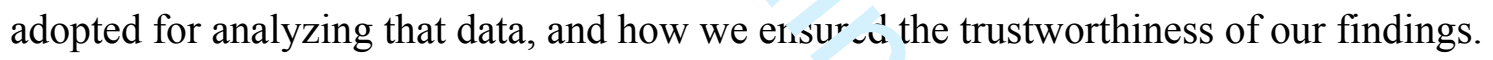

\section{Philosophical stance}

For the current study, as for our empirical source ad es, we adopted a philosophical stance based on pragmatism and the 'pragmatic approach' ( $\left.M_{\boldsymbol{I}_{2}} \mathfrak{2} \mathrm{n}, 2007\right)$ by assuming a postpositivist (empirical realist) ontology (Bryman and Bell, 2003; Pon+_rotto, 2005) and a constructivist-interpretivist (transactional-subjectivist) epistemology (_unliff ${ }_{`}, 2011$; Hamlin, 2015). The study was informed by Tsang and Kwan's (1999) notion of the 'm development through empirical generalization replication, and Berry's (1989) derived etic approach to applied research based on 'replication logic' and 'multiple cross-case comparative analysis' Eisenhardt, 1989). Berry's (1989) emic-etic approach, which involves the use of common methodologies to explore the same phenomena in various settings, followed by comparative analysis of the 
respective findings, has been found to be appropriate when reaching for valid empirical generalizations.

\section{Empirical source data}

The only contemporary Colombian managerial behaviour study suitable for obtaining empirical source data for the purpose of our cross-case/cross-nation comparative study was that of Anon 3 et al. (2015). Because the researchers had gathered data from both public and private sector organizations, the most comparable Mexican study was that of Anon 1 et al, (2013) which had also been used for the Anon 1 et al (2018) comparative study. Therefore, all the raw data and findings generated by these studies were readily available to us, the details of which are shown in Table I.

Methodology of the empirical source studies. Flanagan's (1954) critical incident technique (CIT) was used to obtain concrete examples (c ic ic's incidents-CIs) of effective and ineffective managerial behaviour. The CIs were collected frum ? urr osive samples of managers and nonmanagerial employees. The CIs could relate either to jeh viour exhibited by managers above, at the same level, or below them in the organizational hier at ${ }^{\text {h. }}$. For each CI the researcher posed and strictly adhered to three standard questions, as follows: i) ${ }^{\mathrm{N}}{ }^{\top}{ }_{\mathrm{N}} \mathrm{a}^{\mathrm{t}}$ was the background situation, circumstance or context that led up to the critical inciden y su ' 9 re in mind? ii) What and in what way exactly did the subject (the manager you observed) do/say or not do/say that was either effective or ineffective? and iii) What was the specific result or outcome of the critical incident that you have described and on reflection, why do you perceive/judge this to be an example of 'effective' or 'ineffective' managerial behaviour/ managerial performance?

The collected CIs were subjected to open and axial coding to group them into clusters (behavioural categories) based on their similarity in meaning. Following this step, behavioural statements (BSs) were formulated to reflect the meaning held in common with the CIs ( $\mathrm{n}=3$ to 12 ) 
constituting each behavioural category. As can be seen in Table I, the number of research participants acting as CIT informants was 35 and 27 for the respective Mexican and Colombian studies. Overall, 318 and 267 CIs were collected for each study, respectively. The number of discrete BSs derived from the analyzed Mexican and Colombian CIs was 33 and 53, respectively.

Inset Table I about here

\section{Data analysis used for the present study}

The empirical source data specifically obtained from the Mexican and Colombian studies for our cross-case/cross-nation comparative study were the respective sets of positive (effective) and negative (ineffective) behavioural statements (BSs). We used open coding to first identify the salient unit of meaning (concept/code) of each BS. Then, using axial coding, we compared the BSs (Mexican and Colombian), looking for evidence of sameness, similarity, or congruence of meaning between them (Flick, 2002; Miles and Huberman, 1994). Following Anon 1 et al, (2018), Sameness was found when the sentences or phrases of two or more BSs were considered equal or near equal. Similarity was found when the sentences or phrases were not the same, but the meaning of the BSs was the same. Congruence was when an element of sameness or similarity existed in the phrases and/or key words describing the BSs. Those BSs found to contain meanings that were either the same, or closely similar, or just slightly similar, were referred to as being 'convergent.' Those BSs found to contain meanings that differed and were dissimilar and unlike the meaning of any other BS, as interpreted at a semantic level of understanding, were referred to as being 'divergent.' 
The respective 'convergent' Mexican and Colombian BSs were accordingly grouped into behavioural clusters (categories). Each deduced category was interpreted and labelled with a short statement describing the overarching meaning held in common with all of its constituent Mexican and Colombian BSs. We refer to these behavioural category descriptors as generic behavioural indicators (GBIs) of perceived managerial and leadership effectiveness. The positive and negative Mexican BSs that were found to be 'divergent' were subjected to further interrogation to identify those containing codes/concepts that described an absence of the types of managerial behaviour indicative of one or more of the 'convergent' or 'divergent' positive and negative Colombian BSs; and vice versa. The 'divergent' positive and 'divergent' negative BSs revealed as 'near opposite' in meaning with either 'convergent' negative or 'convergent' positive BSs were deemed to belong to the same respective positive or negative GBI. These GBIs were thus comprised of both effective and ineffective BSs. As shown in Table 2, the BSs underpinning three of the positive (effective) and three of the negative (ineffective) derived GBIs include one or more respective 'near opposite' in meaning BS(s). Details of the common research focus, design, methodology, and data collection/analysis methods adopted by the researchers of our Mexican and Colombian empirical source studies can be found in Hamlin's (2009) book Universalistic Models of Managerial and Leadership Effectiveness. Furthermore, a detailed description of the common CIT protocol followed as closely as possible by these researchers, and how it was applied by the researchers of an equivalent managerial behaviour study in South Korea, can be found in Chai et al.s' book A case of Critical Incident Technique: Perceived managerial and Leadership Effectiveness.

Ensuring trustworthiness of the findings

This was achieved through a process of investigator triangulation (Easterby-Smith et al., 1991) which involved Author 1 conducting a comparative analysis which was then code-cross checked by Author 2 (Gibbs, 2007), and where discrepancies were found between the respective 
interpretations these were resolved through critical discussion. Once agreement was reached the result was sent to Author 3 for a confirmation audit.

\section{Results}

A substantial number of the compared Mexican and Colombian behavioural statements (BSs) were close to identical or similar in substance and meaning. As shown in Table II, 10 out of the 15 'Mexican' positive (effective) BSs are convergent in meaning with 19 of the 26 'Colombian' BSs. Likewise, 14 of the 18 'Mexican' and 17 of the 27 'Colombian' negative (ineffective) BSs are convergent in meaning. As also shown in Table II, five of the nine 'divergent' positive and negative Mexican BSs (MP12; MP14; MP15, MN16, MN18) were found to be 'near opposite' in meaning with one or more of the 'convergent' negative or positive Colombian BSs (CN1; CN15; CP1; CP2; CP3). Of the 17 'divergent' positive and negative Colombian BSs, 4 (CP25; CP26; CN24) were 'near opposite' in meaning with either a 'convergent' negative or positive Mexican BSs (MN7; MN7; MP8). In addition, one of the other 'divergent' positive and negative Colombian BSs (CP22; CN18) were respectively 'near opposite' in meaning with one of the other 'divergent' negative and positive Mexican BSs (MN16; MP14). The derived positive and negative generic behavioural indicators (GBIs) of perceived managerial and leadership effectiveness resulting from our data analysis are shown in the right-hand column of Table II.

Inset Table II about here

As can be seen, the six generic behavioural indicators derived from the respective convergent BSs plus one or more 'near opposite' in meaning BS(s) are typed in a smaller font size and in grey shade, are GBIs: P1, P2, P7, N1, N5 and N9. To illustrate how the BSs underpinning each of the derived GBIs were deduced from the CIT data collected by the researchers of our Mexican and Colombian 
empirical source studies, we present in Figure 1 an example of the data analytic abstraction structure relating to one positive (effective) generic behavioural indicator (GBI: P1).

Inset Figure 1 about here

\section{Discussion}

Our comparative study has revealed more similarities than differences in the way that managerial and non-managerial employees in Mexico and Colombia perceive 'managerial and leadership behavioural effectiveness.' Of the combined Mexican and Colombian positive (effective) BSs and negative (ineffective) BSs, 71\% (29 of the 41) and 69\% (31 of 45) are respectively congruent in meaning. However, when considering also those Mexican BSs that are 'near opposite' in meaning with Colombian BSs, and vice versa, $85 \%$ (35 of 41 ) of the combined positive BSs and $78 \%$ (35 of 45 ) of the combined negative BSs are respectively convergent. As a result, we have deduced 8 positive and 11 negative generic behavioural indicators (GBIs) of perceived managerial and leadership effectiveness relating to the manager's role of managing and leading people, plus an additional positive GBI relating to the importance of looking after customers.

The results of our study suggest that managers in Mexican and Colombian companies are perceived as 'effective' when they: i) provide reward and recognition; ii) make sure employees have good working conditions and the resources necessary to do their job; iii) are mindful in organizing and distributing workload; iv) support employees by listening empathetically and addressing their questions, worrying work problems and/or personal concerns; v) encourage the personal development of employees by providing support for education, training, and allowing employees to make decisions; vi) take into consideration and utilises the suggestions and views of the employees; vii) solve work problems effectively; viii) personally support employees by 
giving them a hand in situations where work is excessive or stressful; ix) ensure good customer service is provided and experienced problems are quickly addressed.

Conversely, both Mexican and Colombian employees consider 'ineffective' those managers who fail to exhibit the type of positive (effective) behaviours mentioned above, as well as those managers who: i) favour some employees over others and treat them unequally; ii) are disrespectful in the way they treat employees by showing rude and arrogant behaviour; iii) humiliate employees in front of others; iv) ignore employee concerns and/or deny problems, and take no action to address or resolve them; v) fail to communicate important information to employees including instructions/directions, and changes that will affect them; vi) act in an arbitrary and autocratic manner [by ignoring suggestions of employee]; vii) manifests unreliable and inconsistent behaviour; viii) exhibit unprofessional behaviour (e.g. getting emotional, losing control, being closed minded, negative to collaboration); ix) do not care about the personal development of their employees; $x$ ) blame employees for problems without any proper investigation and/or take no responsibility for their own mistakes/errors; xi) show poor problem solving and decision- making skills.

However, our comparative study also reveals some differences in the way that managerial and non-managerial employees in Mexico and Colombia respectively perceive behaviours associated with effective and ineffective management and leadership. Whi'. thı research participants of our Mexican empirical source study indicated the need for mar as 4 ?s to: (i) be understanding of employees' personal needs; ii) be fair in their decision making rucess; iii) make recommendations for work improvement; and iv) be understanding of employees' mistakes, their Colombian counterparts considered that effective managers are those who: i) show good planning and organization skills; ii) provide clear directions and instructions; iii) 
show care and concern for the overall well-being of employees; and iv) keep employees properly informed. However, there is nothing within the BS descriptions of these types of managerial behaviour to indicate they are 'country-specific' or 'culture-specific.' We suggest that potentially they could be 'context-general' to both Latin American countries, but this speculation has yet to be demonstrated empirically.

Our findings suggest, despite cultural differences that may exist between Mexico and Colombia, that managers and their subordinates in these two countries perceive 'managerial and leadership behavioural effectiveness' in a similar manner to a great extent. Although traditionally Latin American countries have been considered culturally homogeneous (Lenartowicz and Johnson, 2002), there is also evidence that there are cultural differences among countries in this region. For example, while Hofstede (1980) found Colombia highly 'collectivistic', Trompenaars and Hampden-Turner (1998) found Mexico high on 'individualism.' Nevertheless, the generic behavioural indicators (GBIs) identified in our study do not suggest differences in the perception of managerial and leadership behavioural effectiveness between Mexicans and Colombians based on these two cultural dimensions.

Cultural differences between Mexico and Colombia were also documented by Lenartowicz and Johnson (2002). In their research about comparativ, $m_{\star} r_{\lrcorner}$gerial values in Latin America, they identified that Mexico and Colombia significantly differ wi^^ rę ards to 'civility'. This dimension includes values such as being cheerful, helpful, loving, forgivi.ı. clean, obedient, and polite. Our findings suggest that the behaviours associated with civility are relevant not only for Mexicans but also for Colombians. For example, Mexican employees perceive as effective those managers who are flexible enough to make special concessions to employees and do not make employees feel bad when they make mistakes. These behaviours 
could be associated with the 'civility' dimension identified by Lenartowicz and Johnson (2002).

Similarly, Colombian employees consider ineffective those managers who are disrespectful in the way they treat employees by showing a rude and arrogant behaviour and those managers who humiliate employees in front of others. These behaviours could be interpreted as a lack of civility.

Similarities and differences between Mexico and Colombia have also been identified by the GLOBE study (House et al., 2004). For example, according to GLOBE, being participative is considered a culturally contingent leadership behaviour. In this regard, the findings indicate that exhibiting a participative leadership style is more important for Colombians than Mexicans as an attribute of effective leadership. However, our findings indicate that both Mexican and Colombian employees consider effective those leaders who are open and take employees' suggestions into account. Moreover, whereas the GLOBE findings show that being human oriented as an attribute of effective leaders seems to be more relevant for Colombians than Mexicans, the results of our study indicate that human oriented characteristics such as caring about the well-being of employees and personally supporting employees are important not only for Colombians but also for Mexicans.

\section{Limitations and Directions for Future Research}

We acknowledge two main limitations of our study. The first relates to the sample size and scope of the two compared sets of empirical source data. The number of critical inc ${ }^{i}{ }^{2} \mathrm{n} S \mathrm{BSs}$ obtained from the Mexican source study was 318, while 267 were obtained from the equiluient Colombian study. This difference could be attributed to the fact that the size of the respective samples of research participants secured for these studies was unbalanced, being 35 and 27 for Mexico and Colombia respectively. However, although the number of Colombian participants 
was smaller than the Mexican participants, it was still well within the sample size range of 20 to 40 which is considered appropriate for good qualitative research (Cresswell et al., 2003). If larger samples had been secured for both the Mexican and Colombian studies, this would have led to larger BS data sets, and in turn could have resulted in an even higher proportion of BSs being found convergent in meaning. Thus, we suggest more indigenous replication managerial behaviour studies be carried out in both Mexico and Colombia with the objective of identifying (if possible) the existence of more critical incidents of perceived managerial and leadership effectiveness that could lead to more and/or different behavioral statements. Also, the CIs were collected in two specifics areas of Mexico (Yucatan) and Colombia (Bogota).

In terms of the sample scope, another limitation is that Moreover, the CIs used in this comparative study are derived from participants workıng $\mathrm{n}$ a diverse (in size and industry) range of organizations in the private and public sectors in boti $\mathbf{S}^{-}$sico and Colombia. We suggest conducting replica studies focused on specific industries to tesi ile seneralizability of our findings to these industries. It is possible that more industry focused est ${ }^{2}$. $h$ could lead to different results. However, as Clark et al. (2016) report, the limited number of past studies comparing effective leadership practices across industries, sectors, and job classifications have led to inconclusive results. Furthermore, our Mexican and Colombian studies focused on senior, $\underline{\text { middle, and first-line managers and supervisors. Hence, we suggest including executive leaders }}$ in the subject focus of future studies. Another possibility could be to conduct studies that focus on the managerial behaviours exhibited by top managers only. 
The second main limitation relates to the disproportionate number of male and female research participants secured for both empirical source studies. The number of male participants involved in the Colombian study was twice the number of female participants, whereas the opposite was the case for the Mexican study with the number of female participants being almost double that of male participants. We recommend that more equivalent qualitative managerial behaviour research with larger and more gender balanced samples of participants should be conducted in both countries. This would result in larger numbers of BSs being available for comparison purposes, and could lead to a better and deeper understanding of the similarities and differences between the respective perceptions of 'managerial and leadership behavioural effectiveness' held by Mexican and Colombian managerial and non-managerial employees.

\section{Implications for research and practice}

Our study provides new insights and a better understanding of the expectations of people employed within Mexican and Colombian organizations in terms of what behaviourally distinguishes effective managers from ineffective maıage s. The fact that over $81 \%(\mathrm{n}=70)$ of the compared BSs obtained from both source studies have ? ? en mutually validated suggests they could be applied widely within the public sector and private sector of both countries.

Furthermore, we suggest the 9 positive GBIs and 11 negative GBIs of perceived managerial and leadership behavioural effectiveness resulting from our study, combined with the findings of Anon 1 et al.'s (2018) equivalent Mexico-Argentina comparative study, suggest the possibility of similar high degrees of commonality and empirical generalization existing across multiple Latin American countries. This lends support for Velasquez and Salgado's (2015) call for a new ideal Latin-American leadership profile to be identified. 
Our findings are relevant to Mexican and Colombian expatriates. Mexican expatriates managing employees in Colombia and Colombian expatriates managing employees in Mexico can learn from our findings that although there are a significant number of similarities in the way the managerial behavioural effectiveness is perceived, there are also some differences. Therefore, the idea of using in Colombian companies all the managerial practices that have been successful in Mexico and vice versa may not necessarily lead to success.

Our findings could be used to assist human resource development (HRD) professionals in preparing Mexican and $\mathrm{Cc}^{\circ} \mathrm{v}_{n}{ }^{n}$ sian executives for international assignments in these countries. Understanding the perceptions of different stakeholders in the organization about managerial and leadership effectiveness is important. Research suggests that when managers and subordinates share similar perceptions, performance improves, thereby having a positive impact on the organization (Testa, 2001). HRD professionals who train Mexican executives for assignments in Colombia or train Colombian executives for assignments in Mexico should, we suggest, put greater emphasis on those specific managerial practices that are perceived effective and ineffective by both Mexican and Colombian employee at all levels within public and private sector organizations. Furthermore, we suggest they should additionally place special emphasis on those other managerial behavioural practices that seem from our study to be relevant only for organizations in Mexico or Colombia. However, we recommend they should be mindful that future empirical research might demonstrate these practices to be context-general, and thus relevant and transferable to both countries.

Lastly, our findings could also be of relevance to those HRD professionals of international companies with subsidiaries in Mexico and/or Colombia. For example, our finr.ilzs could be relevant to HRD professionals in various European Union (EU) countries due to the EU 
free trade agreements with Mexico and Colombia (Grieger, 2019) which have resulted in an increased amount of trade. Both Mexico and Colombia are among the top five recipients of FDI in Latin America while the Netherlands, Spain, France, Germany, and Italy are among the top 10 investors in the region (UNCTAD, 2019). Thus, it is expected that these investments will result in increasing numbers of European executives working in Mexico and/or Colombia who will need to understand how to properly manage the workforce in these countries. European companies with subsidiaries in both Mexico and Colombia may find the findings of this comparative study useful for preparing their executives for international assignments in these Latin American countries.

\section{Conclusion}

The findings of our cross-case comparative study sugger: that people within Mexican and Colombian organizations perceive 'managerial and l€ader ,hip behavioural effectiveness' in very similar ways. They also suggest that despite cultural differences between Mexico and Colombia, as underlined by some cross-cultural studies, there are more similarities than differences with regards to how people in these countries perceive effective and ineffective managers. This latter finding supports those researchers (e.g. Bass, 1996) whose studies indicate that culture may not have a significant impact on leadership behaviour, and that globalization may have led to leadership practices which could be effective across countries (Gentry and Sparks 2012; House and Aditya, 1997; Robie et al., 2001). On the contrary, our findings lend little support to the findings of researchers such as Clark et al. (2016) who suggest effective leadership practices may be country-specific rather than country-general. Our findings lend support to the notion of 
'universalistic' managerial behaviours that could be used across all Latin American countries to effectively manage and lead employees.

We hope our study will act as a spur for other management researchers to conduct more equivalent indigenous qualitative managerial behaviour studies in all Latin American countries. The empirical evidence so generated could then be used to develop (if possible) a 'new ideal' Latin-American profile, model, or taxonomy of 'managerial and leadership behavioural effectiveness'.

\section{References}

Bass, B. (1996), “Is there universality in the full range model of leadership?”, International Journal of Public Administration, Vol. 16 No. 6, pp. 731-761.

Berry, J. (1989), “Imposed etics-emics-derived etics: The operationalization of a compelling Idea”, International Journal of Psychology, Vol. 24 No. 6, pp. 21-35.

Borman, W.C. and Brush D.H. (1993), “More progress ‘sward a taxonomy of managerial performance requirements", Human Performance Vol. 6 No. 1, pp.1-21.

Bryman, A. and Bell, E. (2015), Business Research Me hu. , (4 ${ }^{\text {th }}$ ed.), University Press, Oxford, UK.

Chai, D-S; Jeong, S; Kim, S. and Hamlin R.G. (2019), A Case of Critical Incident Technique: Perceived Managerial and Leadership Effectiveness London: Sage.

Clark, J., Quast, L., Jang, S., Wohkittel, J., Center, B., Edwards, K., and Bovornusvakool, W. (2016), "GLOBE Study culture clusters: Can they be found in Importance ratings of managerial competencies?" European Journal of Training and Development, Vol. 40 No. 7, pp.534-553.

Cresswell, J.W., Plano Clarke, V., Gutmann, M. and Hanson, W. (2003), Advances in 
mixed methods design, Tashakkori, A. and Teddie, C. (Eds), Handbook of Mixed Methods in Social and Behavioural Sciences, Sage, Thousand Oaks, CA, pp.209-240

Cunliffe, A.L. (2011), “Crafting qualitative research: Morgan and Smircich 30 years on”, Organizational Research Methods, Vol. 14 No. 4, pp. 647-673.

Davis, A. and Nayebpour, M. (2004), “Obreros (workers) against gerentes (managers) chaning values in the Mexican workplace", Latin American Business Review, Vol. 5 No. 1, pp. 71-93.

Dorfman, P.W. and Howell, J.P. (1997), “Leadership in Western and Asian countries: commonalities and differences in effective leadership", Leadership Quarterly, Vol. 8 No. 3, pp. 233-242.

Easterby-Smith, M., Thorpe, R. and Lowe, A. (1991), Management Research: An Introduction. Sage, London.

Eisenhardt, K.M. (1989), "Building theories from case study research", Academy of Management Review, Vol.14, pp. 532-550.

Elvira, M. and Davlla, A. (2005) "Emergent directions for human resource management research in Latin America, ” International Journal of Human Resource Management, Vol 16 No. 12, pp. 2265-2282.

Flanagan, J.C. (1954), “The critical incident technique”, Psychological Bulletin, Vol. 51 No. 4, pp. 327-358.

Flick, U. (2002), An Introduction to Qualitative Research, Sage, 2nd ed, London.

Gentry, W.A. and Sparks, T.E. (2012), “A convergence/divergence perspective of leadership competencies managers believe are most important for success in organizations: a cross-cultural multilevel analysis of 40 countries", Journal of Business and Psychology, 
Vol. 27 No. 1, pp. 15-30.

Gibbs, G.R. (2007), Analyzing Qualitative Data, Sage, London.

Grieger, G. (2019), "EU trade with Latin America and the Caribbean”, available at:

https://www.europarl.europa.eu/RegData/etudes/IDAN/2019/644219/EPRS_IDA(2019)6

44219_EN.pdf (accessed 31 October 2021)

Hamlin, R.G. (2009), “Universalistic Models of Managerial and Leadership Effectiveness: A Cumulative and Multiple Cross-Case Empirical Study of Effective and Ineffective Managerial Behaviour", VDM Verlag Dr. Muller, Saarbricken, Germany.

Hamlin, R (Bob). (2015). "Paradigms, philosophical prisms and pragmatism in HRD Research”, Saunders, M.N.K and Tosey, P. (Eds.), Handbook of Research Methods on Human Resource Development, Edward Elgar Publishing Ltd, Cheltenham, UK, pp.1331).

Hofstede, G. (1980), Culture's Consequences, Sage Publications, Beverly Hills, CA. House, R.J. and Aditya, R.N. (1997), “The Social Scientific Study of Leadership: Quo Vadis?”, Journal of Management, Vol. 23 No. 3, pp. 409-465

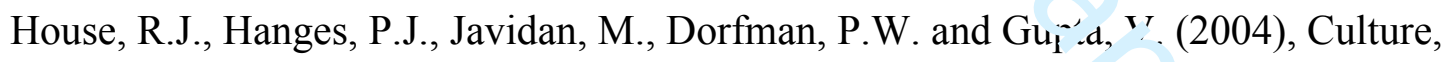
Leadership, and Organizations: The GLOBE Study of 62 Sor etıs, Sage, London.

Iglesias, I. (2017), “Between Mexico and Colombia”, Negocios Promexicr. Jul r/August: 64-65. Retrieved from http://www.promexico.gob.mx/documentos/revista-negocios/pdf/jul-ago 2017.pdf

Lenartowicz, T. and Johnson, J. (2002), “Comparing managerial values in twelve Latin American countries: An exploratory study”, Management International Review, Vol. 42 No. 3, pp. 279-307. 
Luthans, F. and Doh, J.P. (2012), International Management: Culture, Strategy, and Behaviour. 8th ed. McGraw-Hill Irwin, New York, N.Y.

Miles, M.B. and Huberman, A.M. (1994), Qualitative Data Analysis, Sage, Thousands Oak, CA. Sage.

Morgan D. L. (2007), "Paradigms lost and pragmatism regained: Methodological implications of combining qualitative and quantitative methods", Journal of Mixed Methods Research, Vol. 1 No. 1, pp. 48-76.

Najera, M. (2008), “Managing Mexican workers: Implication of Hofstede's cultural Dimensions”, Journal of International Business Research, Vol. 7 No. 2, pp. 107-126.

Nicholls-Nixon, C., Davila, J., Sanchez, J. and Rivera, M. (2011) “Latin America management research: Review, synthesis, and extension,” Journal of Management, Vol. 37 No. 4, pp. $1178-1227$.

Ponterotto, J. (2005), “Qualitative research in counseling psychology: A primer on research paradigms and philosophy of science", Journal of Counseling Psychology, Vol 52 No. 2, pp. 126-136.

Procolombia 2018. Mexico: A country that make investments in Colombia. Retrieved from https:/www.investincolombia.com.co/news/917-mexico-a-country-that-make-investmentsin-colombia.html

Robie, C., Johnson, K.M., Nilsen, D. and Fisher Hazucha, J. (2001), “The right stuff: Understanding cultural differences in leadership performance”, Jourr al Development, Vol. 20 No. 7, pp. 639-650.

Secretaria de Economia (2018), “Balanza Comercial de Mercancías de México”, (Balanza commercial 1993 - 2018, productos 2008 - 2018). SNIEG. Información de Interés SAT, SE, BANXICO, INEGI. http://www.economia-snci.gob.mx/sic_php/pages/estadisticas/ 
Stephens, G. and Greer, C. (1995), “Doing business in Mexico: Understanding cultural Differences”, Organizational Dynamics, Vol. 24 No. 1, pp. 39-55.

Testa, M.R. (2001), "Hospitality Leaders: Do they know how their employees feel about them?”, Cornell Hotel and Restaurant Administration Quarterly, Vol. 42 No. 6, pp. 80-89.

The Pacific Alliance (2018), “Alianza del Pacífico Visión 2030”. Retrieved from https://alianzapacifico.net/download/alianza-del-pacifico-vision-2030-version-final-julio24/

Trompenaars, F. and Hampden-Turner, C. (1998), Riding the Waves of Culture:

Understanding Diversity in Global Business, 2nd ed, McGraw-Hill, New York, NY.

Tsang, E.K.K. and Kwan, K. (1999), “Replication and theory development in organizational science: A critical realist perspective”, The Academy of Management Review, Vol. 24 No. 4, pp. 759-780.

Tsui, A.S. (1984), “A role set analysis of managerial reputation”, Organizational Behaviour and Human Performance, Vol. 34 No. 1, pp. 64-96.

Tsui, A.S. (1990), “A multiple-constituency model of effectiveness: An empirical examination at the human resource subunit level", Administrative Science Quarterly, Vol. 35 No. 3, pp. 458-483.

Tsui, A.S. (1994), “Reputational effectiveness: Toward a mutual responsiveness framework”, Research in Organizational Behaviour, Vol. 16, pp. 257-307.

Tsui, A.S. and Ashford, S. (1994) “Adaptive self-regulation: A process view of murlaorrial Effectiveness", Journal of Management, Vol. 20 No. 1, pp. 93-121.

UNCTAD (2019), "World Investment Report", available at: 
https://unctad.org/system/files/official-document/wir2019_en.pdf (accessed 31 October 2021)

Velázquez Valadez, G. and Salgado Jurado, J. (2015) “Estudio comparativo México-Argentina: perfil ideal del líder bajo el modelo de liderazgo empático", Revista del Centro de Investigación. Universidad La Salle, Vol 11 No. 43, pp. 61-92.

Yukl, G. (2012), "Effective leadership behavior: What we know and what questions need more Attention", Academy of Management Perspectives, Vol. 26 No 4, pp. 66-85.

Yukl, G., Gordon, A. and Taber, T. (2002), “A hierarchical taxonomy of leadership behavior: Integrating a half century of behavior research", Journal of Leadership and Organizational Studies, Vol. 9 No. 1, pp. 15$\lrcorner 1$. 


\section{Comparative Study of the Perceptions of Mexican and Colombian Employees about Managerial and Leadership Behavioural Effectiveness}

Table I

Empirical Source Data Used For the Present Derived Etic Study

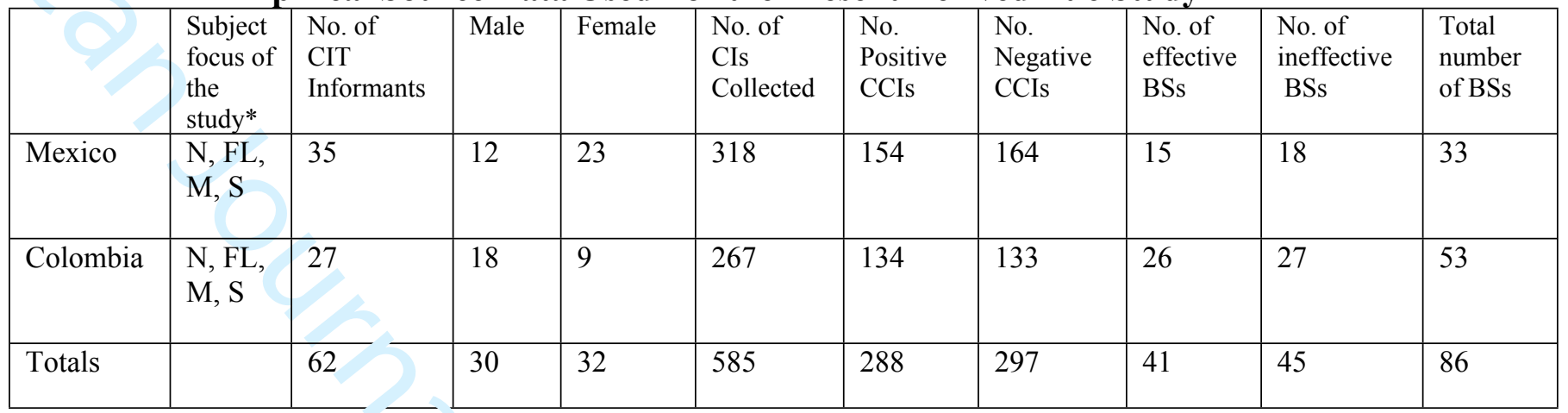

* Subject Focus: S-Senior manager. M-Middle managers. FL-First line managers. N-Non manager

Table II

Comparison of the "Mexican" and "Colombian" positive (effective) and negative (ineffective) behavioural categories

\begin{tabular}{|c|c|c|}
\hline $\begin{array}{c}\text { Mexico (M) } \\
\text { Positive (MP) (Effective) Behavioural } \\
\text { Statements } \\
\text { BSs }\end{array}$ & $\begin{array}{c}\text { Colombia (C) } \\
\text { Positive (CP) (Effective) Behavioural } \\
\text { Statements } \\
\text { BSs }\end{array}$ & $\begin{array}{c}\text { Deduced Positive } \\
\text { (Effective) Generic } \\
\text { Behavioural Indicators } \\
\text { (GBIs) }\end{array}$ \\
\hline $\begin{array}{c}\text { Convergent } \\
(\text { Same or similar }) \\
\end{array}$ & $\begin{array}{c}\text { Convergent } \\
(\text { Same or similar })\end{array}$ & \\
\hline $\begin{array}{l}\text { MP1. Provides rewards and recognizes } \\
\text { employees in front of others }\end{array}$ & $\begin{array}{l}\text { CP 1 Manager rewards deserving } \\
\text { employees (e.g. for working extra hard; } \\
\text { achieving company revenue goals) } \\
\underline{(\mathrm{MN} 18)} \\
\text { CP } 2 \text { Manager gives public recognition } \\
\text { to the successes/good performance of } \\
\text { his/her employees (MN18) } \\
\text { MN 18 Does not recognize or reward employees } \\
\text { (CP1. CP2) }\end{array}$ & $\begin{array}{l}\text { P1) Managers provide } \\
\text { reward and recognition }\end{array}$ \\
\hline $\begin{array}{l}\text { MP2. Makes sure employees have } \\
\text { good working conditions }\end{array}$ & $\begin{array}{l}\text { CP } 3 \text { Manager fights for and secures } \\
\text { resources for his his/her employees, } \\
\text { and/or acts as an advocate with higher } \\
\text { management on their behalf (MN16) } \\
\text { MN } 16 \text { Does not provide good working } \\
\text { conditions and proper materials that enable } \\
\text { employees to do their work (CP3) }\end{array}$ & $\begin{array}{l}\text { P2) Managers make sure } \\
\text { their employees have good } \\
\text { working conditions and the } \\
\text { resources necessary to do } \\
\text { their job }\end{array}$ \\
\hline $\begin{array}{l}\text { MP3 Distributes workload without } \\
\text { overloading employees }\end{array}$ & $\begin{array}{l}\text { CP } 4 \text { Manager organizes well the roles, } \\
\text { responsibilities, and deployment of and } \\
\text { collaboration between employees }\end{array}$ & $\begin{array}{l}\text { P3) Managers are mindful of } \\
\text { employees in organizing and } \\
\text { distributing their workload; }\end{array}$ \\
\hline
\end{tabular}


MP4 Addresses employees' concerns and questions

MP5 Listens to the employees' needs

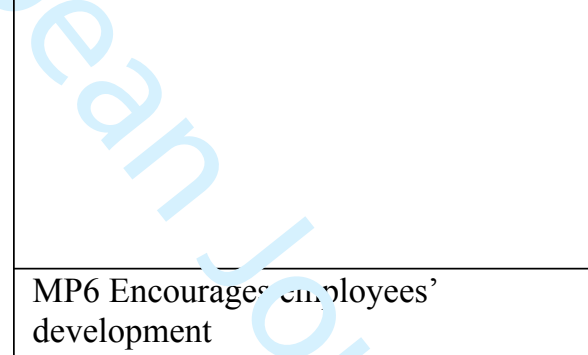

flexibility that allows employees to use their initiative, develop ideas, and make their own decisions

CP 8 Manager actively delegates to and empowers his/her employees to make their own decisions

CP 9 Manager actively supports 'mployees' endeavours to develop dn ${ }^{j} v_{1}$ advance their careers and/or settle ir ${ }^{+} \mathrm{o}$ a new job (e.g. giving promotir . ${ }^{1}$ opportunities; helping with trans ${ }^{f}, \mathrm{r} /$ relocation within organization)

CP 10 Manas ar encourages and supports ' $\mathrm{m}$ ' oye $\mathrm{s}$ to develop and

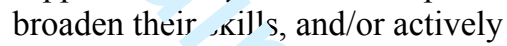
arranges traini $\mathrm{g}$ fo them and/or trains them personally

CP 11 Manager encuurag is and supports employees to att .ci work related (trade/industrial) ear ing events such s fairs, conv _...t1ons, and conferences

CP 12 Manager is open to the ideas/suggestions of employees and listens to them

CP 13 Manager accepts and implements suggestions from employees

CP 14 Manager seeks and utilizes the views of employs in his decisions, and/or involves them in discussions and problem-solving activities

MP8 Solves problems in an effective manner (CN24)

CP 15 When confronted by imposed or emergent changes in objectives the manager adapts to the changed situation in a positive/proactive manner
P4) Managers support employees by listening empathetically and addressing their questions, worrying work problems and/or personal concerns

P5) Managers encourage the personal development of employees by providing support for education, training, and allowing employees to make decisions;
P6) Managers take into consideration and utilises the suggestions and views of the employees;

P7) Managers solve work problems effectively 


\begin{tabular}{|c|c|c|}
\hline & $\begin{array}{l}\text { CP } 21 \text { Manager maintains good control } \\
\text { of the agenda and/or proceedings of } \\
\text { meetings }\end{array}$ & \\
\hline & $\begin{array}{l}\text { CP 22 Manager takes action to } \\
\text { improve/optimize the efficient use of } \\
\text { employee time and other resources } \\
\text { (MN16) } \\
\text { MN 16 Does not provide good working } \\
\text { conditions and proper materials that enable } \\
\text { employees to do their work (CP22) }\end{array}$ & \\
\hline & $\begin{array}{l}\text { CP } 23 \text { Manager shows care and } \\
\text { concern for the health and well-being } \\
\text { of his/her employees }\end{array}$ & \\
\hline & $\begin{array}{l}\text { CP } 24 \text { Manager instigates social } \\
\text { interaction with employees outside of } \\
\text { work }\end{array}$ & \\
\hline & 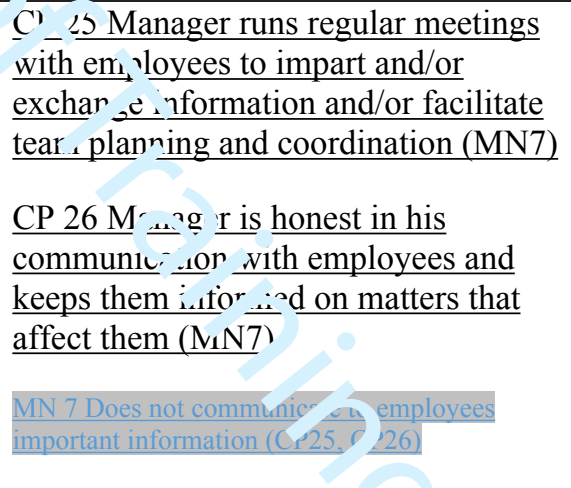 & \\
\hline $\begin{array}{c}\text { Negative (MN) (Ineffective) } \\
\text { Behavioural Statements } \\
\text { BSs }\end{array}$ & 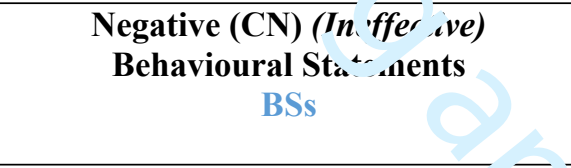 & $\begin{array}{c}\text { Deduced Negative } \\
\text { (Ineffective) Generic } \\
\text { Behavioural Indicators } \\
\text { (GBIs) } \\
\end{array}$ \\
\hline $\begin{array}{c}\text { Convergent } \\
\text { (Same or similar) }\end{array}$ & $\begin{array}{c}\text { Convergent } \\
\text { (Same or similar })\end{array}$ & \\
\hline $\begin{array}{l}\text { MN } 1 \text { Favors some employees over } \\
\text { others based on friendship not } \\
\text { performance } \\
\text { MN } 2 \text { Does not distribute work fairly } \\
\text { MN } 3 \text { Overloads employees with work } \\
\text { of other people who miss work }\end{array}$ & $\begin{array}{l}\text { CN 1 Manager treats employees } \\
\text { unfairly by showing favoritism and/or } \\
\text { being influenced by political } \\
\text { connections (MP12) } \\
\text { MP12 Makes decisions in a fair manner (CN1) } \\
\text { CN } 2 \text { Manager treats employees } \\
\text { unequally (e.g. assigning tasks; making } \\
\text { concessions; applying rules; dealing } \\
\text { with mistakes) }\end{array}$ & $\begin{array}{l}\text { employees over others and } \\
\text { treat them ujnequally }\end{array}$ \\
\hline $\begin{array}{l}\text { MN } 4 \text { Exhibits an arrogant and rude } \\
\text { attitude }\end{array}$ & $\begin{array}{l}\text { CN } 3 \text { Manager shows lack of respect } \\
\text { and civility to employees }\end{array}$ & $\begin{array}{l}\text { N2) Managers are } \\
\text { disrespectful in the way they } \\
\text { treat employees by showing } \\
\text { rude and arrogant behaviour; }\end{array}$ \\
\hline
\end{tabular}




\begin{tabular}{|c|c|c|}
\hline $\begin{array}{l}\text { MN } 5 \text { Makes employees feel bad in } \\
\text { front of others when they make } \\
\text { mistakes }\end{array}$ & $\begin{array}{l}\text { CN } 4 \text { Manager talks to employees, } \\
\text { usually in front of others, in a way that } \\
\text { demeans, humiliates, and undermines } \\
\text { their self-confidence }\end{array}$ & $\begin{array}{l}\text { N3) Managers humiliate } \\
\text { employees in front of others; }\end{array}$ \\
\hline $\begin{array}{l}\text { Does not acknowledge problems } \\
\text { or } c \text { them }\end{array}$ & $\begin{array}{l}\text { CN } 5 \text { Manager procrastinates in } \\
\text { addressing issues } \\
\text { CN } 6 \text { Manager ignores employee } \\
\text { concerns or complaints and/or } \\
\text { notification of potential problems, and } \\
\text { takes no action to address or resolve } \\
\text { the issues }\end{array}$ & $\begin{array}{l}\text { N4) Managers ignore } \\
\text { employee concerns and/or } \\
\text { deny problems, and take no } \\
\text { action to address or resolve } \\
\text { them }\end{array}$ \\
\hline 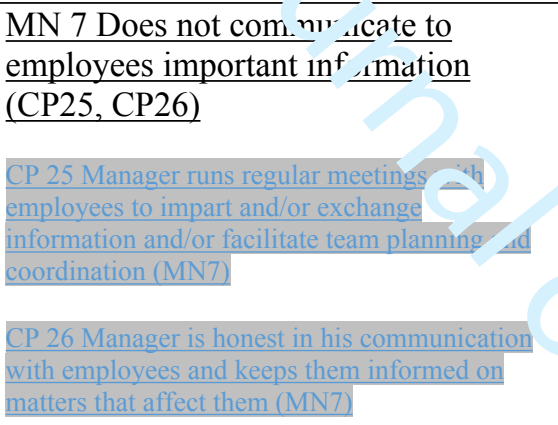 & $\begin{array}{l}\text { CN } 7 \text { Manager fails to give to } \\
\text { employees clear, precise, and/or timely } \\
\text { orders/instructions/directions on what } \\
\text { is required of them } \\
\text { CN } 8 \text { Manager delays and/or withholds } \\
\text { from employees information about } \\
\text { rganizational rules, regulations or } \\
\text { th ag ss that will directly affect them }\end{array}$ & $\begin{array}{l}\text { N5) Managers fail to } \\
\text { communicate important } \\
\text { information to employees } \\
\text { including instructions/ } \\
\text { directions, and changes that } \\
\text { will affect them; }\end{array}$ \\
\hline $\begin{array}{l}\text { MN } 8 \text { Makes arbitrary decisions } \\
\text { MN } 9 \text { Breaches company’s policies }\end{array}$ & 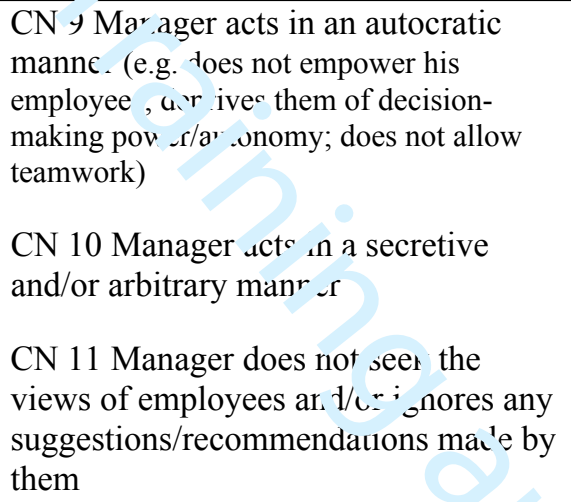 & $\begin{array}{l}\text { N6) Managers act in an } \\
\text { arbitrary and autocratic } \\
\text { manner [by ignoring } \\
\text { suggestions of employee] }\end{array}$ \\
\hline $\begin{array}{l}\text { MN } 10 \text { Does not do what he/she says } \\
\text { he/she is going to do }\end{array}$ & $\begin{array}{l}\text { CN } 12 \text { Manager exhibits inconsistent } \\
\text { and/or unreliable behaviour }\end{array}$ & $\begin{array}{l}\text { N7) Managers manifests } \\
\text { in - diable and inconsistent } \\
\text { vehaviour }\end{array}$ \\
\hline MN 11 Lacks professionalism & $\begin{array}{l}\text { CN } 13 \text { Managers gets emotionally } \\
\text { upset and loses control } \\
\text { CN } 14 \text { Manager displays a negative } \\
\text { attitude or closed mind to new ideas or } \\
\text { suggestion from his employees, and/or } \\
\text { to working collaboratively with other } \\
\text { departments }\end{array}$ & $\begin{array}{l}\text { N8) Managers exhibit } \\
\text { unprofessional behaviour } \\
\text { (e.g. getting emotional, } \\
\text { losing control, being closed } \\
\text { minded, negative to } \\
\text { collaboration) }\end{array}$ \\
\hline $\begin{array}{l}\text { MN } 12 \text { Does not care about the } \\
\text { education and training of employees }\end{array}$ & $\begin{array}{l}\text { CN 15 Manager deprives employees of } \\
\text { support they require to perform better } \\
\text { in their current jobs and/or resolve a } \\
\text { (e.g. remote worker support; } \\
\text { opportunity to improve in the job, or }\end{array}$ & $\begin{array}{l}\text { N9) Managers do not care } \\
\text { about the personal } \\
\text { development of their } \\
\text { employees; }\end{array}$ \\
\hline
\end{tabular}




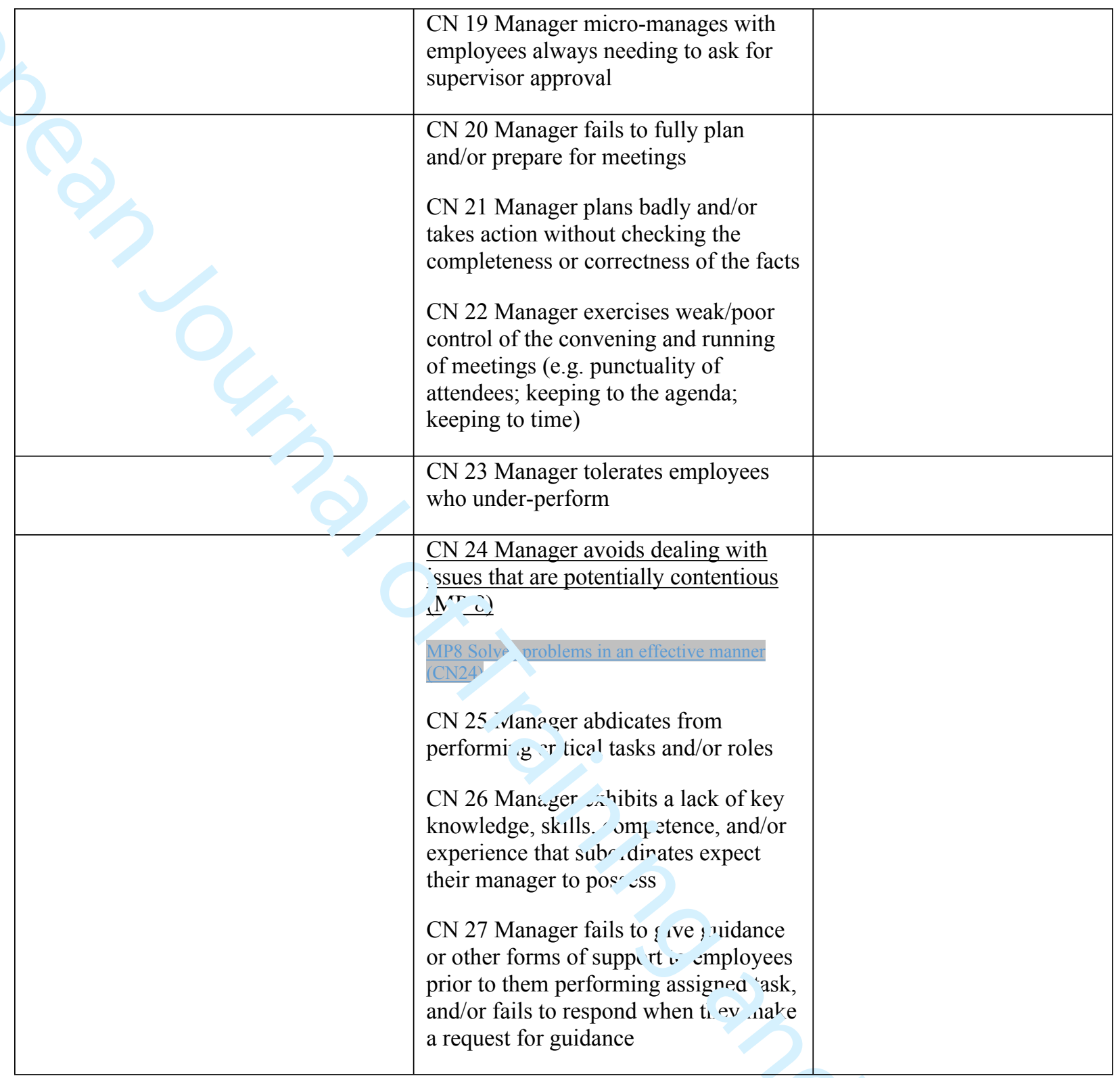

Note: The underlined Mexican and Colombian BSs are those that are 'near opposite' in meaning with the corresponding Colombian and Mexican BS indicated in the bracket at the end of each statement 


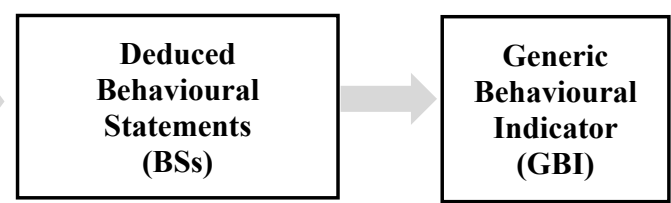

\begin{tabular}{|l|}
\hline Mexican Study \\
MP1. Provides \\
rewards and \\
recognizes \\
employees in \\
presence of others
\end{tabular}

\section{Colombian Study Positive (Effective) CIs}

Hard extra work was performed next to top management. Top management asked employee to show up in his office after finished. He rewarded him with 5 days off because of the hard extra work he had observed.

Monetary incentives are given if the company reaches the revenue goals.

Although in many occasions employees have not asked for raises to the Manager, the Manager asks for raises when she sees that someone deserves a salary increase.

\section{Mexican Study Negative (Ineffective) CIs}

A large project was scheduled that would require extra work by one particular department. The manager did not give any extra benefits.

The manager does not provide any type of reward to outstanding employees to keep them motivated.

The manager tried to ignore the comments about the accomplishment of the employee. Also, the manager tried to diminish the accomplishment.

\section{Colombian Study}

Manager communicates employee's success to organization and is made public.

Supervisor presents goals and good results in public, making employee proud.

Senior level manager addresses [i.e. gives recognition to] employee personally in public making him feel important. The boss made public the excellent service one of his subordinates made and gave her an award.

\section{$1^{\text {st }}$ Order Concepts}

An employee did an outstanding job on three projects in a row and the manager gave employee an extra two days of The manager recognized the work of the employee and gave The department manager congratulated everybody in the rer

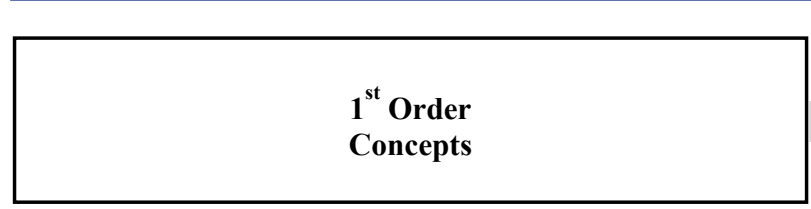

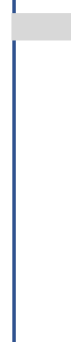

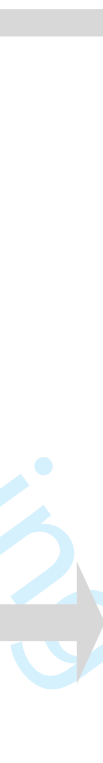

\section{Colombian Study}

CP 1 Manager rewards deserving employees (e.g. for working extra hard; achieving company revenue goals)

Mexican Study

MN 18 Does not recognize or reward employees

\section{Colombian Study}

CP 2 Manager gives public recognition to the successes/good performance of his/her employees
Managers provide reward and recognition 